\title{
EFFECT OF RHIZOBIUM INOCULANT ON NODULATION, YIELD AND YIELD TRAITS OF CHICKPEA (CICER ARIETINUM L.) IN FOUR DIFFERENT SOILS OF GREATER RAJSHAHI
}

\author{
Shahriar Zaman*, M. Abdul Mazid and Golam Kabir ${ }^{1}$ \\ Department of Genetic Engineering and Biotechnology, University of Rajshahi, Rajshahi 6205, \\ Bangladesh; ${ }^{1}$ Department of Botany, University of Rajshahi, Rajshahi 6205, Bangladesh; \\ *Corresponding author (e-mail: szbobbie@gmail.com)
}

\begin{abstract}
This study shows that enhancement of soil fertility along with the yield of chickpea due to nodulation by the Rhizobium is possible to some extent. Data on plant height $(\mathrm{cm})$ at maturity, primary branches/plant, days to flower, pods/plant, pod dry weight/plant (g), seeds/pod, seed dry weight/pod (g), 50 seeds weight (g), nodules/plant, fresh weight of nodules/plant and dry weight of nodules/plant were considered to assess the effect of nodulation in chickpea. Soils treated with Rhizobium always showed higher values than control regarding total nitrogen and organic matter (\%). Campus soil showed the highest value for organic matter (\%) and $\mathrm{N}$ content but Cholonbil soil exhibited the highest value for number of seeds per pod. All the parameters for growth analysis yielded greater values for treated soils compared to that of the control.
\end{abstract}

Key words: Rhizobium, nodulation, yield trait, chickpea, soil.

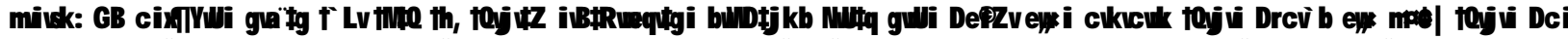

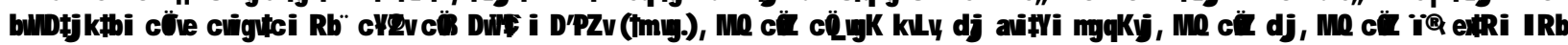

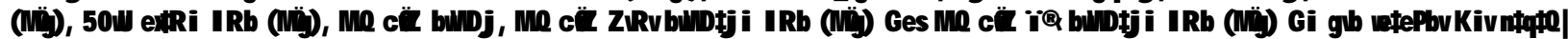

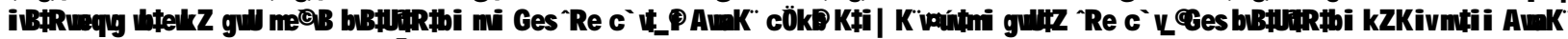

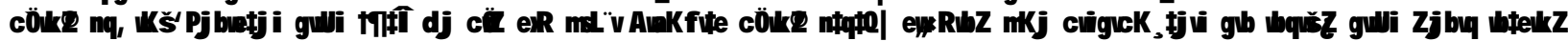

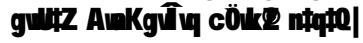

\section{Introduction}

Chickpea (Cicer arietinum L.), a winter crop, is the third major pulse crop in Bangladesh and belongs to the family of Vicieae. It stands the $5^{\text {th }}$ in respect of area (13,915 ha) and production (10,380 tons), and the $2^{\text {nd }}$ in consumption priority (BBS 2004). India is the world leader in chickpea (Bengal gram) production followed by Pakistan and Turkey. The pulse is a helpful source of zinc, folate and protein. It is also very high in dietary fibre (6\%) and thus, a healthy source of carbohydrates. It provides dietary calcium (49-53 mg/100 g) and contains high amount of minerals such as phosphorous (340 mg/l00 g), magnesium (140 mg/100 g), iron (7 $\mathrm{mg} / \mathrm{l00} \mathrm{g})$. Moreover, chickpeas are low in fat content and most of it is polyunsaturated (source: United States Department of Agriculture (USDA) National Nutrient Database, Standard Reference No: 18 \& 21).

Chickpeas have a well developed tap root having 3-4 rows of well defined lateral roots. The tap roots and the laterals have large lobed nodules in the upper $30 \mathrm{~cm}$ layer from soil surface. They nodulate upon infection with cowpea group of Rhizobium. Within this group, the chickpea Rhizobium is specific and nodulates only the
Cicer genus (Raju and Samuel 1976; Gaur and Sen 1981). So, inoculation is necessary when chickpeas are cultivated in virgin land or are introduced into new areas (Rupela and Dart 1980). Nodulation in chickpeas starts at 10-12 days after planting. The active nodules are pink in colour due to the presence of leghaemoglobin, and are capable of fixing atmospheric nitrogen. The nitrogen fixing process continues up to 40-50 days after sowing in warm climates. In cooler climates, it may continue more than 100 days, depending on soil moisture and temperature (Dart 1974). Nodules lose their activity with age and start senescing. Inoculations with Rhizobium strains produce a greater number of nodules. Rhizobia are aerobic, rod shaped, motile, gram negative, heterotrophic, and nonspore forming bacteria, which live freely in soil and in the root region of leguminous and non-leguminous plants. Rhizobia fix atmospheric nitrogen and thus, not only increase the production of inoculated crops but also leave a fair amount of nitrogen in the soil, which benefits the subsequent crops (Agarwal 1998). Most of these bacteria are very sensitive to soil water deficit, which adversely affects their nitrogen fixation capacity and hence the productivity of whole legume plant (Miller and Wood 1996). They are also sensitive to 
higher salt concentration (Wilson 1994) and are capable of growing at $200 \mathrm{mM}$ salt concentration, but the growth is more abundant at lower salt concentration (Rafiq 1997). Moreover, the inhibitory effects of other soil microorganisms such as bacteria, fungi and actinomycetes (Nutman 1965), toxic effects of fungicides, herbicides and other plant protectants as well as temperature affect the growth and survival of rhizobia (Subba Rao 1985; Islam and Dart 1975; Date 1989; Date and Ratcliff 1989).

Unfortunately, this important crop is much neglected and little work is done so far for its improvement in this country, where its yield per acre is low. Compared to other Asian countries, soils in Bangladesh are quite poor in nutrient elements, especially Rajshahi regions are deficient in nitrogen fixing Rhizobium which causes poor yield of chickpea (Bhuiyan et al. 1998; Khanam et al. 1994). Most of the farmers of our country cannot use recommended doses of various fertilizers because of their poor economy. To assess the ability of the rhizobia strains for nodulation under varying conditions of soil from different agro-ecological zones of Greater Rajshahi was the main objective of this study.

\section{Materials and Methods}

A high yielding chickpea variety namely BARICHOLA-3 used as plant material was supplied from Biometrical Genetics Laboratory of the Genetic Engineering and Biotechnology Dept. of Rajshahi University. Experimental soils were collected from four different areas namely Barind region of Kakanhat, Chapai Nawabgong district, Cholonbil area of Natore district, the river bank of Padma in Rajshahi district and the university campus of Rajshahi. In this experiment gram negative bacteria (Rhizobium sp.) collected from nodules of Dhaincha, was used for effective symbiosis with legumes for $\mathrm{N}_{2}$ fixation. YEMA and LB liquid medium were used as culture media in the laboratory for isolation and culture of bacterial strain.

After sun drying for 7 days, collected soils were grounded and kept in an electric oven at $60{ }^{\circ} \mathrm{C}$ for $12 \mathrm{~h}$ and then fairly mixed with compost proportionately. These soil samples were analyzed for $\mathrm{pH}$ and nutrient contents by the method directed by SRDI, Shyampur, Rajshahi. Healthy, unbroken, firm and preferably pink nodules of Dhaincha were collected and washed in water. They were immersed in $0.1 \%$ acidified $\mathrm{H}_{\mathrm{g}} \mathrm{Cl}_{2}$ for 4-5 min and washed repeatedly with distilled water and then dipped into $70 \%$ ethanol for a while. The nodules were then crushed with few drops of water and the fluid was spreaded on YEMA plates with glass rod. The plates were incubated at $26^{\circ} \mathrm{C}$ for 10 days. Large and small gummy colonies of bacteria emerged in 4-5 days which were transferred and sub cultured on YEMA plates for several times to obtain pure rhizobial colony. It was then transferred into a conical flask containing LB medium ( $\mathrm{pH} 7.5$ ) and were placed on a shaker for 24 $\mathrm{h}$ at $155 \mathrm{rpm}$ at $30^{\circ} \mathrm{C}$ and finally, was preserved at $4{ }^{\circ} \mathrm{C}$.

The experiment was laid out with a control and three replications. A total of sixteen earthen pots were filled up with the prepared soils, of which four pots were used for each soil type. Liquid cultured media containing Rhizobium strain was then sprayed thoroughly in inner part (1-1.5 inches below the surface) of soil in three pots of each soil type and the remaining one was used as control. Finally, collected fresh and dry seeds of chickpea (Cicer arietinum) were inoculated using slurry method and sown in all the sixteen pots, 15-20 seeds in each pot, for growing. During the experiment the soils in pots were kept moistened very slightly. It may be mentioned here that the bio-fertilizers were used within 90 days of its production. After sowing, each pot was labeled according to soil types and treatment. During the period of investigation an insecticide (Nagos 100 EC) was sprayed gently on the leaves at the rate of $1 \mathrm{ml}^{-1} \mathrm{~L}^{-1}$ water. All other required management was taken.

Over the period of investigation seedling heights of all the experimental plants were measured and recorded at three different time intervals of maturity such as 15, 25 and 40 days after sowing (DAS) before the final harvest. At physiological maturity of the plants the harvest was done. Five plants each from a control and three treated replications of each of the four soil types were harvested for determination of the grain and biological yield and their components. Plant height at maturity $(\mathrm{cm})$, primary branches per plant, days to flower, pods per plant, pod dry weight per plant (g), seeds per pod, seed dry weight per pod (g), 50 seeds weight (g), nodules per plant, fresh weight of nodules per plant and dry weight of nodules per plant were recorded at the final harvest.

\section{Results and Discussion}

Soil analysis: Before setting the experiment and after harvest of the crop data on soil nutrients were recorded (Table 1). The present study reflects primarily the soil properties due to absence and presence of soil bacteria Rhizobium. The initial soil (before use) was found to be alkaline except Barind one, which was acidic in nature. This soil generally includes calcareous floodplain. In the initial soil organic matter was low and this is why its 
fertility level was not high. In this case, only the treated soil of Campus was found to show an increased value (2.32). That was different from all other values and significantly high compared to that of control and initial soil. The values recorded for total nitrogen in all the cases of this study indicated also the low level of fertility, though potassium (K) was medium in all the four types of soils before and after use in this experiment. On the other hand, phosphorous (P), sulphur (S) and zinc (Zn) status were very high as according to BARC (2005).

Table 1. Properties of different soil types ( $\bar{x}$ values) before and after treatment with Rhizobium sp.

\begin{tabular}{|c|c|c|c|c|c|c|c|c|c|}
\hline \multicolumn{3}{|c|}{ Soil types } & $\mathrm{pH}$ & OM (\%) & $\begin{array}{c}\text { Total N } \\
\text { (\%) }\end{array}$ & $\begin{array}{c}\mathrm{K} \\
\mu \mathrm{m} \cdot \mathrm{g}^{-1}\end{array}$ & $\begin{array}{c}\mathrm{P} \\
\mu \mathrm{m} \cdot \mathrm{g}^{-1}\end{array}$ & $\begin{array}{c}\mathrm{S} \\
\mu \mathrm{m} \cdot \mathrm{g}^{-1}\end{array}$ & $\begin{array}{c}\mathrm{Zn} \\
\mu \mathrm{m} \cdot \mathrm{g}^{-1}\end{array}$ \\
\hline \multirow{3}{*}{ Barind } & & $1^{\mathrm{st}}$ & 5.30 & 1.25 & 0.07 & 0.47 & 30.00 & 24.00 & 3.99 \\
\hline & \multirow{2}{*}{$2^{\text {nd }}$} & Control & 8.40 & 1.00 & 0.05 & 0.54 & 49.80 & 7.80 & 5.21 \\
\hline & & Treated & 8.38 & 0.97 & 0.05 & 0.50 & 57.20 & 9.70 & 5.25 \\
\hline \multirow{3}{*}{ Campus } & \multicolumn{2}{|r|}{$1^{\text {st }}$} & 7.50 & 0.80 & 0.05 & 0.44 & 11.20 & 15.80 & 0.53 \\
\hline & \multirow{2}{*}{$2^{\text {nd }}$} & Control & 7.64 & 0.66 & 0.04 & 0.31 & 85.0 & 5.80 & 4.18 \\
\hline & & Treated & 8.54 & 2.32 & 0.11 & 0.25 & 76.70 & 4.50 & 5.79 \\
\hline \multirow{3}{*}{ Cholonbil } & \multicolumn{2}{|r|}{$1^{\text {st }}$} & 7.90 & 1.25 & 0.07 & 0.21 & 39.20 & 17.00 & 3.17 \\
\hline & \multirow{2}{*}{$2^{\text {nd }}$} & Control & 8.55 & 1.52 & 0.07 & 0.31 & 93.90 & 3.40 & 7.20 \\
\hline & & Treated & 8.39 & 1.36 & 0.07 & 0.43 & 95.60 & 5.60 & 7.63 \\
\hline \multirow{3}{*}{ Padma } & \multirow{3}{*}{$2^{\text {nd }}$} & $1^{\mathrm{st}}$ & 8.20 & 1.49 & 0.09 & 0.25 & 17.20 & 12.00 & 0.27 \\
\hline & & Control & 8.56 & 0.56 & 0.03 & 0.23 & 99.20 & 3.30 & 4.18 \\
\hline & & Treated & 8.61 & 0.95 & 0.05 & 0.24 & 97.90 & 2.30 & 5.26 \\
\hline
\end{tabular}

$1^{\text {st }}=$ soil before use; $2^{\text {nd }}=$ soil after use

Table 2. Effect of Rhizobium treatments on the height of seedlings ( $\overline{\mathrm{x}}$ values) in chickpeas grown in different soil types.

\begin{tabular}{|c|c|c|c|c|c|c|c|c|}
\hline \multirow{3}{*}{ Soil types } & \multicolumn{6}{|c|}{ Height of seedlings $(\mathrm{cm})$} & \multirow{3}{*}{ Control $\overline{\mathrm{x}} \pm \mathrm{SD}$} & \multirow{3}{*}{ Treated $\bar{x} \pm S D$} \\
\hline & \multicolumn{2}{|c|}{15 DAS } & \multicolumn{2}{|c|}{25 DAS } & \multicolumn{2}{|c|}{$40 \mathrm{DAS}$} & & \\
\hline & Control & Treated & Control & Treated & Control & Treated & & \\
\hline Barind & 5.07 & 5.46 & 8.35 & 9.71 & 13.45 & 14.90 & $8.96 \pm 4.22$ & $9.86 \pm 4.47$ \\
\hline Campus & 4.96 & 5.60 & 8.83 & 10.27 & 13.65 & 15.89 & $9.15 \pm 4.35$ & $10.59 \pm 5.15$ \\
\hline Cholonbil & 5.62 & 6.76 & 9.66 & 9.80 & 15.50 & 15.88 & $10.26 \pm 4.96$ & $10.81 \pm 4.64$ \\
\hline Padma & 5.632 & 6.50 & 9.83 & 11.59 & 15.48 & 16.27 & $10.31 \pm 4.94$ & $11.45 \pm 4.89$ \\
\hline
\end{tabular}

DAS = days after sowing; three replications were used per experiment.

Growth analysis: Growth analysis has been done in the present study as it relates the influence of Rhizobium sp. and different soil types on the growth and yield of chickpea.

Seedling height: At the 15 days of sowing, it was observed that seedling heights were always higher for the treated soil types comparing to that of control. Highest and lowest values for control were found in Padma and Campus soil types, respectively. But in case of treated soil, Cholonbil showed highest value and Barind showed lowest value (Table 2). Data at 25 DAS revealed that Padma soil showed highest values for control as well as for treated plants whereas Barind showed lowest values for both. Average seedling heights of treated soil types were greater than those of controls. Similar results were observed for the data measured at 40 DAS. Growth analysis of measured seedling heights for each and every type of soil at three different date of sowing revealed that seedling heights were always higher for the treated soil types comparing to those of control.

Yield and yield components: The results on the yield and yield components of chickpea in four types of soil due to treatment with Rhizobium sp. (Table 3) revealed that the average weight of 50 seeds grown in Barind soil was less than those grown in the rest of the soils.

Plant height: In this case, all types of soil for both control and treated showed more or less similar results. Plants of control and treated Barind soil gave highest values $(41.42 \mathrm{~cm} \& 42.58 \mathrm{~cm})$ and lowest values (37.25 $\mathrm{cm} \& 39.74 \mathrm{~cm}$ ) were recorded for Campus soil. In case of control, plants of Barind and Padma soils showed nearly similar results. In the present study plants grown 
in control and treated soil of Barind showed highest values for plant height at maturity. It may be mentioned that Pahwa and Patil (1983) found increased plant height of Dolichos lablab due to inoculation of pasture legumes with cowpea Rhizobium. Singh et al. (1984) found notable variation for biological nitrogen fixation at different growth stages of Pisum sativum.

Table 3. Effect of Rhizobium treatment on yield and yield components ( $\overline{\mathrm{x}}$ values) of Cicer arietinum planted in different soil types.

\begin{tabular}{|c|c|c|c|c|c|c|c|c|}
\hline \multicolumn{2}{|c|}{ Soil types } & $\begin{array}{c}\text { Plant height at } \\
\text { maturity (cm) }\end{array}$ & $\begin{array}{c}\text { No. of } \\
\text { primary } \\
\text { branches }\end{array}$ & $\begin{array}{c}\text { Days to } \\
\text { flower }\end{array}$ & $\begin{array}{c}\text { No. of } \\
\text { pods/plant }\end{array}$ & $\begin{array}{c}\text { Dry weight of } \\
\text { pods (g) }\end{array}$ & $\begin{array}{c}\text { No. of } \\
\text { seeds/pod }\end{array}$ & $\begin{array}{c}\text { Av. weight of } \\
50 \text { seeds (g) }\end{array}$ \\
\hline \multirow{2}{*}{ Barind } & Control & $41.42^{*}$ & $2.50^{*}$ & $61.00^{*}$ & 82.32 & 22.23 & $1.40^{*}$ & $5.56^{*}$ \\
\cline { 2 - 9 } & Treated & $42.58^{* *}$ & $2.85^{* *}$ & $61.67 * *$ & 97.28 & 26.27 & $1.80^{* *}$ & $5.79^{* *}$ \\
\hline \multirow{2}{*}{ Campus } & Control & 37.25 & $2.33^{*}$ & 66.50 & 99.17 & 26.78 & $1.20^{*}$ & $6.02^{*}$ \\
\cline { 2 - 10 } & Treated & 39.74 & $2.50^{* *}$ & 63.33 & 105.68 & 28.53 & $1.40^{* *}$ & $6.09^{* *}$ \\
\hline \multirow{2}{*}{ Cholonbil } & Control & 39.52 & 2.75 & 63.00 & 119.56 & 32.28 & 2.00 & $6.21^{*}$ \\
\cline { 2 - 10 } & Treated & 41.34 & 3.27 & 61.67 & 133.33 & 35.99 & 3.00 & $6.30^{* *}$ \\
\hline \multirow{2}{*}{ Padma } & Control & $41.05^{*}$ & $2.50^{*}$ & 57.00 & 92.48 & 24.97 & $2.00^{*}$ & $6.07^{*}$ \\
\cline { 2 - 10 } & Treated & $41.80^{* *}$ & $2.54^{* *}$ & 56.00 & 102.66 & 27.72 & $2.40^{* *}$ & $6.18^{* *}$ \\
\hline
\end{tabular}

$*$ and $* *$ indicate non-significant differences between control and treatment groups for the particular character; three replications were used per experiment.

Table 4. Effect of Rhizobium treatment on the number and weight of chickpea root nodules in different soil types.

\begin{tabular}{|c|c|c|c|c|}
\hline \multicolumn{2}{|c|}{ Soil types } & $\begin{array}{c}\text { No. of } \\
\text { nodules/plant* }\end{array}$ & $\begin{array}{c}\text { Fresh wt. of nodules (g) } \\
\overline{\mathrm{x}} \pm \mathrm{SD}\end{array}$ & $\begin{array}{c}\text { Dry wt. of nodules (g) } \\
\overline{\mathrm{x}} \pm \mathrm{SD}\end{array}$ \\
\hline \multirow{2}{*}{ Barind } & Control & 4 & $0.032 \pm 0.015$ & $0.012 \pm 0.005$ \\
\cline { 2 - 5 } & Treated & 9 & $0.143 \pm 0.58$ & $0.038 \pm 0.014$ \\
\hline \multirow{2}{*}{ Campus } & Control & 2 & $0.025 \pm 0.012$ & $0.012 \pm 0.006$ \\
\cline { 2 - 5 } & Treated & 5 & $0.142 \pm 0.68$ & $0.053 \pm 0.022$ \\
\hline \multirow{2}{*}{ Cholonbil } & Control & 5 & $0.083 \pm 0.041$ & $0.039 \pm 0.021$ \\
\cline { 2 - 5 } & Treated & 1 & $0.215 \pm 0.107$ & $0.058 \pm 0.025$ \\
\hline \multirow{2}{*}{ Padma } & Control & 4 & $0.050 \pm 0.022$ & $0.007 \pm 0.003$ \\
\cline { 2 - 5 } & Treated & 3 & $0.209 \pm 0.102$ & $0.082 \pm 0.040$ \\
\hline
\end{tabular}

* Ten plants were used for each parameter and three replications were used per experiment.

Number of primary branches: In case of the number of primary branches Cholonbil soil showed slight differences but that was of highest value for both the control and treatment. Values for this character in Barind and Padma soil showed more or less similar results and Campus soil showed the lowest value.

Days to flower: Here, the chickpea plants of all types of treated soil took fewer days to flower than control. Plants grown in Padma soil took 57.00 (lowest) days to flower whereas Campus soil took 66.00 (highest) days. For treated soil types, lowest and highest values were also found in Padma and Campus (56.00 and 63.33 days), respectively. Remaining types showed nearly similar results.

Number of pods/plant: In this study highest value for number of pods per plant was found in the treated soil of Cholonbil whereas, the lowest value was shown by chickpea plants grown in Campus soil. It was observed that treated soils always showed higher values than control for all types of soil. Khurana et al. (1984) reported highly significant differences between varieties, bacterial cultures and variety $\times$ culture interaction. They also reported that Hisar culture highly influenced plant height and pods/plant of soybean. Pawar and Ghulghule (1977) stated that branches/plant, number of pods and 1000-seed weight of Vigna radiata were not found to be affected due to treatment with Rhizobium.

Dry weight of pods: The soil of Cholonbil was found to be an ideal whereas the soil of Barind gave the lowest value for this character. This is similar to the findings of Gowda et al. (1979) who reported increased fresh weight of pods/plant in cowpea due to inoculation with lignite based culture of Rhizobium. 
Number of seeds/pod: In case of number of seeds per pod Cholonbil soil gave the highest average value and the lowest value was found in control of Campus soil. Here, control soils of Barind and Campus showed nearly similar results (1.40 and 1.20) whereas Padma and Cholonbil soil (control) gave the same result (2.00). But the values of treated soils were always greater than that in the control.

Average weight of 50 seeds: All types of soil except the control Barind showed more or less similar values, particularly among the treated soil. But when it was compared among the control and treated soils, the observed differences indicated effective response of chickpea plants to Rhizobium.

Number of nodules/plant: Out of all types of soil, nodulation of chickpea plants in Cholonbil soil showed the highest value for both control and treated types. On the other hand, the lowest values were found for both control (2) and treated (5) Campus soil. Plants of the treated soil always showed more nodulation than the uninoculated control soil (Table 4). Rhizobium strains differ in their ability to nodulate and in their capacity to fix nitrogen. Response differs due to different population levels of native and added strains of Rhizobium and due to the competitive ability of native Rhizobium with the added strain (Rupela and Dart 1980). Symbiotic nitrogen fixation by Rhizobium meets the $\mathrm{N}_{2}$ requirement of the crop and leaves $40-108 \mathrm{~kg} / \mathrm{ha}$ in the soil (Subba Rao 1976).

Fresh weight of nodules: The highest value $(0.215 \mathrm{~g})$ for this character was found for treated Cholonbil soil and the lowest $(0.142 \mathrm{~g})$ for treated Campus soil. Control soil of those two regions also showed high (0.083 g) and low (0.025 g) average fresh weight of the nodules. Values for all type of control soil were nearly similar but for treated soils it showed differences. The values for treated soil, however, were always higher than the control soil (Table 4).

Dry weight of nodules: Similar result was observed for control and treated soil as found for the fresh weight of nodules. In case of control soil, the highest and lowest values were recorded for Cholonbil (0.039 g) and Campus (0.007 g), respectively. On the other hand, nodule of plant of Padma soil showed the highest value $(0.082 \mathrm{~g})$ and the lowest value $(0.038 \mathrm{~g})$ was showed by Barind soil (Table 4). Hossain et al. (1999) reported that nitrogen up to $20 \mathrm{lb} / \mathrm{acre}$ increased the number and weight of nodules. Dry weight of nodules per plant compared to number of nodules was more closely related to seed yield as reported by Khurana et al. (1984).

In the present study soil status of four different regions of Greater Rajshahi and yield potential of chickpea due to the use of Rhizobium indicated that all the four types of soil were very poor in terms of fertility. In addition, the yield of chickpea was found to increase considerably due to Rhizobium inoculation. Findings on nitrogen content in soil and number of seeds per pod obtained in treated Campus and Cholonbil soil revealed vice versa characteristic. Moreover, all the studied parameters showed greater values for treated soils compared to that of control. The present findings therefore suggest that chemical fertilizers may be used in a reduced rate by the farmers for increasing grain production, but considering the productivity of the soil of a region efforts should also be oriented towards augmenting biological nitrogen fixation mediated by the soil microorganisms like Rhizobium.

Acknowledgements: The authors are thankful to The University Grants Commission of Bangladesh for providing the research grant and also to Professor S. Alam Cytogenetics Laboratory, Department of Botany, Rajshahi University, for providing the research facilities.

\section{References}

Agarwal SK. 1998. Environmental Biotechnology. APH Publ. Corp., New Delhi. pp. 57-63.

BARC (Bangladesh Agricultural Research Council). 2005. Fertilizer Recommendation Guide. Bangladesh Agricultural Research Council, Farm Gate, Dhaka.12 pp.

BBS (Bangladesh Bureau of Statistics). 2004. Year Book of Agricultural Statistics of Bangladesh. Bangladesh Bureau of Statistics. Ministry of Planning and Development, Govt. of the People's Republic of Bangladesh, Dhaka. 63 pp.

Bhuiyan MAH, Khanam D, Khatun MR, and Hassan MS. 1998. Effect of molybdenum, boron and Rhizobium on nodulation, growth and yield of chickpea. Bull. Inst. Trop. Agric., Kyushu Univ. 21: 1-7.

Dart PJ. 1974. Development of root-nodule symbiosis: The infection process. In: ed., The Biology of Nitrogen Fixation (ed. Quispel A.), pp. 381-429. NorthHolland Research Monographs: Frontiers of Biology, 33. Amsterdam, North-Holland.

Date RA. 1989. Growth, nodulation and nitrogen fixation in Stylosanthes: Effect of different day/night root temperatures. Expl. Agric. 25: 461-472.

Date RA and Ratcliff D. 1989. Growth, nodulation and nitrogen fixation in Stylosanthes: Effect of different root temperatures at two shoots temperatures. Expl. Agric. 25: 446-460. 
Gaur YD, Sen AN. 1981. Cultural and biochemical characteristics of root nodule bacteria of chickpea (Cicer arietium L.). Zbl. Bakt. 11. Abst. 136: 307-316.

Gowda ST, Hegde SV, Bagyaraj DJ. 1979. Rhizobium inoculation and seed pelleting in relation to nodulation growth and yield of cow pea (Vigna unguiculata L.). Curr. Res. 8(3): 42-43.

Hossain AKM, Khanam D, Bhuiyan MAH, Rahman MHH. 1999. On-farm experience of the application and adoption of biological nitrogen fixation technology in Bangladesh. Bangladesh J. Agril. Res. 24(2): 375-382.

Islam R, Dart PJ. 1975. Studies on legume nodulation: effect of temperature on the symbiosis of Vigna radiate (Green gram) and Vigna mungo (Black gram). Rothamsted report for 1974. 247 pp.

Khanam D, Rahman MHH, Begum D, Haque MA, Hossain AKM. 1994. Inoculation and varietals interaction of chickpea (Cicer arietinum L.) in Bangladesh. Thai. J. Agric. Sci. 27: 123-130.

Khurana SR, Lakshminarayana K, Narule Neeru 1984. Response pattern of soybean (Glycine max) genotypes as influenced by nodulation traits. Indian. J. Agric. Res. 18: 193-196.

Miller KJ and Wood JM. 1996. Osmo-adaptation by rhizosphere bacteria. Ann. Rev. Microbiol. 50: 101136.

Nutman PS. 1965. Origin and development of root nodules. Handbook Plant Physiol. 12: 1355-1379.

Pahwa MR and Patil ED. 1983. Response of some pasture legumes to cow pea Rhizobium inoculation. Leg. Res. 6: 89-90.
Pawar NB and Ghulghule JN. 1977. Study of synergistic effects of Rhizobium, Azotobacter and nitrogen on the grain yield and other yield attributes of mung (Phaseolus aureus syn. Vigna radiata). Trop. Grain Leg. Bull. 9: 22-25.

Rafiq S. 1997. Effect of different salt concentrations on the growth of Rhizobium. J. Bacteriol. 179: 211-216.

Raju KS and Samuel AV. 1976. Response of gram (Cicer arietinum L.) to different rhizobial inoculants. Madras Agric. J. 63: 582-586.

Rupela OP and Dart PJ. 1980. Research on symbiotic nitrogen fixation by chickpea at ICRISAT. In: Proc International workshop on chickpea Improvement. ICRISAT. Hyderabad, pp. 161-167.

Singh S, Ghai BS and Randhawa GS. 1984. Genetic Studies on Biological $\mathrm{N}_{2}$ Fixation in Peas (Pisum sativum L.). USG Pub. Ludhiana, India. pp. 69-77.

Subba Rao NS. 1976. Field response of legumes in India to inoculation and fertilizer application. In: Symbiotic Nitrogen Fixation in Plants. (ed. Nutman PS), pp. 255-268. Cambridge Univ. Press, Cambridge.

Subba Rao NS. 1985. Biofertlizer in Agriculture ( $2^{\text {nd }}$ edn). Oxford and IBH Publ. Co. New Delhi, India.

Wilson JR. 1994. Salinity effects on Rhizobium nodulation and nitrogen fixation. In: Current Development in Salinity and Drought Tolerance of Plants, pp. 58-77. CSIRO, Brisbane, Australia.

Manuscript received on 16 June 2011 and revised on 5 December 2011 